\title{
АНАЛІТИЧНА МОДЕЛЬ ДОСЛІДЖЕННЯ РЕЦЕПЦЇ̈ УКРАЇНСЬКОЇ ЛІТЕРАТУРИ В ІНОКУЛЬТУРНОМУ ПРОСТОРІ: УРОКИ УЧИТЕЛЯ ПРОФЕСОРКИ РОКСОЛАНИ ПЕТРІВНИ ЗОРІВЧАК
}

\author{
Ірина Одрехівська
}

\author{
Львівський національний університет імені Івана Франка, \\ вул. Університетська, 1, м. Львів, Україна, 79000 \\ iryna.odrekhivska@lnu.edu.ua
}

\begin{abstract}
Ця стаття - це спроба розвинути і запропонувати системне та грунтовне переосмислення праць Р. П. Зорівчак на одну з головних тем іiї наукових пошуків - українсько-англійських літературних взаємин крізь призму художнього перекладу. Враховуючи концептуальні й історіографічні орієнтири розвідок дослідниці, а також “силові точки” в рецептивних студіях професорки - історія сприйняття Тараса Шевченка, Івана Франка та Лесі Українки і входження їхнього творчого досвіду завдяки англомовним інтерпретаціям у культурний простір Великобританії та США, Канади та Австралії, авторка представляє модель аналізу рецепції української літератури в цільовому культурному полі. Подана модель актуалізує п’ять аналітичних вимірів у вивченні рецепції перекладної літератури: аналіз інституційних структур, які диктують політику перекладу для культури-реципієнта; осмислення цільової історії культури, що полягає у розумінні естетичного горизонту читачів і впливу минулих практик на сучасні; аналіз вектору діалогічності цільової культури у певному часопросторі (диференціація чи солідаризація зі світовими літературними тенденціями загалом та вихідною літературою зокрема); вивчення персонологічного чинника в перекладі, а саме габітусу й світоглядної позиції перекладача; аналіз системи вибору, контекстуалізації та стратегій перекладу українських творів для культури реципієнта.

Ключові слова: рецепція, переклад, українська література, культурний трансфер, перекладна література, перекладознавство, політика перекладу.
\end{abstract}

Вступ. Ураховуючи транснаціональні соціокультурні тенденції на початку XXI ст. та функціонування англійської мови як lingua franca в сьогоднішньому багатоетнічному універсумі, можна стверджувати, що сучасний англомовний простір - це вже не географічний ареал, а світовий інтелектуальний ландшафт, на якому “оприсутнення” української літератури, та й культури загалом, стає мірилом власного dignitas. Безумовно, за останні роки бачимо позитивні тенденції, а саме формування інституційного середовища, яке популяризує українську етнокультурну ідентичність та сприяє створенню нового рецепційного клімату для трансформації сприйняття української літератури: при МЗС України сформовано Український інститут, напрямлений на представлення української культури у світі, при Міністерстві

Одрехівська I., 2020 
культури засновано Український інститут книги, що має на меті популяризувати українську літературу за кордоном і стимулювати переклади, а також Український культурний фонд 3 широкою програмою культурних проектів. 3 такої перспективи, як колись влучно вказала Марина Новикова, “світові саме час, мабуть, побачити себе в українському світовидчому люстрі” [8, с. 301].

Проте вагомим, навіть іманентним фокусом постає вивчення рецепції української культури в минулому, що дає змогу ідентифікувати “відправну точку”, тобто окреслити вже сконструйований літературний образ України, та провести аналіз ефективності механізмів представлення творів в інокультурній системі координат. Такий ракурс доводить релевантність урахування історичноїканви сприйняття, адже “легко виплітати цілість тільки з цільної нитки” [2, с. 11]. Саме цю “програмну” нитку залишив нам дослідницький проект професорки Роксолани Петрівни Зорівчак, який чи не вперше масштабно висвітлює історію та рецепцію перекладів української поезії та прози в англомовному просторі XIX - XX ст., а також окреслює траєкторії репрезентації української класики на початку XXI ст. Без сумніву, це зумовлює актуальність цих студій сьогодні. Зосібна, крім монографічних досліджень “Фразеологічна одиниця як перекладознавча категорія (на матеріалі перекладів творів української літератури англійською мовою)" (Львів, 1983) та “Реалія і переклад (на матеріалі перекладів української прози)” (Львів, 1989), системно описують цю проблематику розділ “Українсько-англійські літературні взаємини", підготовлений Р. П. Зорівчак для п’ятитомного видання “Українська література в загальнослов'янському і світовому літературному контексті” (Київ, 1988) [5], а також серія статей: “Сприйняття творчості та особистості Івана Франка як символу інтелектуальної України в англомовному світі” [3], “Шевченкознавство в англомовному світі: історія, своєрідності, ключові здобутки (1876-2014)” [6], “Творчість Лесі Українки в англомовному світі” [4] та низка інших. Сформована хронологія перекладацьких подій, так званий “літопис" українського слова в англомовному обширі, дає нам підстави змістити акценти й “децентрувати” спостереження в площину методів дослідження рецепції та сформованого дискурсу в інтерпретації української літератури за кордоном. Отож, мета цієї статті запропонувати системне і грунтовне переосмислення праць Р. П. Зорівчак з питань репрезентації української літератури у світі, розгорнути діалог з цими поглядами та розвинути їх у цілісну модель дослідження рецепції перекладної літератури у цільовому культурному полі.

Аналіз останніх досліджень і публікацій. За останні два десятиліття у світовому літературознавчому дискурсі спостерігаємо переорієнтацію понятійного розуміння концепції “світової літератури” Й. В. Гете як гармонійного поєднання різних національних літератур. П. Казанова у своїй праці "La rểpublique mondiale des lettres" (“Республіка світового письменства”) говорить про нерівність у світі літератури, оскільки письменники з менш поширених мов й надалі залишаються невидимими, а відтак доводить актуальність системи “літературного капіталу” певної культури (вслід за теорією П. Бурдьє), який нагромаджується завдяки політиці успішних перекладів [13]. 3 цього погляду, переклад стає засобом власного культурного самоствердження та набуття капіталу, щобільше-можливістю побачити 
Себе поза межами звичного й безпечного національного простору. Д. Демрош ще більше радикалізує розуміння світової літератури у книзі "What is World Literature?" (“Що таке світова література?”), трактуючи її не як канон текстів, а як модус їхнього обігу, руху та прочитання між контекстами, епохами й мовами; тож світова література - це твори, “здобуті" в перекладі [14]. С. Зонтаг у розвідці 2007 р. "The World as India” (“Світ як Індія") теж підкреслює, що переклад - це “серцево-судинна система світової літератури” [18]. Тому-то питання “культурного трансферу” (в термінології М. Еспаня) та рецепції перекладів стали фундаментальними у новочасних наукових дискусіях про світовий літературний процес, які - серед іншого - засвідчують одностайність поглядів щодо міждисциплінарного вивчення цієї проблеми на перетині перекладознавства, порівняльного літературознавства та імагології, лінгвокультурології, історії й соціології літератури, напрацювань гендерних студій тощо.

Отож, ця стаття пропонує якісно нове прочитання доробку Р. П. Зорівчак, виходячи 3 новітніх шукань закордонних дослідників та доповнюючи їх для побудови цілісної, різнорівневої моделі дослідження рецепції перекладної літератури у цільовому культурному полі.

Методологія дослідження. 3 опертям на загальнонаукові методи аналізу та синтезу, індукції та моделювання, дослідницька пропозиція цієї студії - побудова всеохопної моделі вивчення рецепції перекладів у цільовій культурі - основана на теоретико-критичній та історико-фактографічній перспективах. Вихідним теоретичним пунктом $\epsilon$ напрацювання з рецептивної естетики (В. Ізер, Г. Р. Яусс, Р. Барт), полісистемної теорії (І. Івен-Зогара та Г. Турі) й теорії символічної влади П. Бурдьє, а також новітні концепції з розуміння світових літературних практик та ролі перекладу (від наукових проєктів П. Казанови, Д. Демроша та С. Баснетт до колективних видань за редакцією Р. Мейлерц і Д. Ройг-Санз [16], Б. Нельсона та Б. Меєр [17]). Відповідно, враховуючи теоретичну складову, критичний ракурс дає можливість оцінити позиціонування перекладацького проєкту в системі цільової культури, а також подальше “життя” твору в новому контексті на основі перекладацьких рецензій, відгуків та інших епітекстів, адаптацій і подальших обробок. Підгрунтям історико-фактографічної перспективи стали вже окреслені праці Р. П. Зорівчак, котрі резюмують “віхові” переклади, групують та актуалізують події перекладацького процесу, які репрезентують українську літературу, а також віддзеркалюють усі етапи підготовки, видання та сприйняття цих інтерпретацій у діахронії. Звісно, ключовим орієнтиром історико-фактографічної перспективи також є серія бібліографічних покажчиків М. Тарнавської [19], які фіксують усі доступні англомовні перекладні праці українських текстів.

Результати дослідження та їхнє обгрунтування. Естетика рецепціїлітературного твору, яку розвинули Г. Р. Яусс та В. Ізер з Константського університету вслід за основоположними твердженнями Р. Інгардена, декларує ключові константи теорії рецепції, зосібна:

1) значущість твору породжує не сам текст, а реципієнт, який конкретизує його значення та намагається зробити текст зрозумілим і перекладним [1, с. 348]; 
2) рецепція твору проходить у межах культурного й антропологічного контексту [1, с. 367], тобто протікає у “горизонті сподіваного”, відтак залежить від часового (історичного) і просторового бачення та розуміння світу [1, с. 367]. Такий взаємозв'язок доводить, що рецепція не $\epsilon$ виключно суб'єктивною конструкцією, а має інтерсуб' єктивний характер;

3) важливим аспектом залишається “зміна горизонту" між наперед заданим сподіванням і закладеним новим змістом, іншими словами, рецепція передбачає також актуальне переформатування естетичної дистанції між досвідом та інновацією. Адже естетичний досвід у комунікаційному процесі можна поділити на три чини: (а) преформативний (нормодавчий), (б) мотивуючий (нормотворчий) та (в) трансформативний (нормоборчий) [1, с. 400].

Ці вихідні твредження визначають класичне розуміння рецепції; зокрема дефініція, подана у Літературознавчій енциклопедії 2007 р., декларує, що рецепція - це сприймання ідей, образів, мотивів, сюжетів із творів чи літератур та “їх творче осмислення, що зумовлене читацьким попереднім досвідом, мовною компетенцією, естетичними смаками, навичками сприйняття художніх феноменів" [7, с. 319]. Відповідно, рецепція перекладу (сприймання ідей, мотивів та образів перекладного твору й їхне подальше творче осмислення) залежить від того, наскільки він функціонально “вписується” в окреслений культурно-історичний період, у певні форми і жанри, які мають успіх у загальному дискурсі цільової культури, або ж наскільки естетичний досвід реципієнтів готовий трансформуватися та “конкретизувати" новаторські тексти. 3 огляду на це, сценарій рецепції перекладного твору також зумовлений характером цільової полісистеми, яка формує “горизонт сподівань" щодо сприйняття іноземної літератури, оскільки - якщо брати до уваги теорії І. ІвенЗогара та Г. Турі - перекладні твори можуть або займати пріоритетне місце (тому що література ще відносно слабка, перебуває у процесі художнього становлення чи проходить кризовий етап), або залишатися все-таки вторинними по відношенню до оригінальних, які домінують серед читацької аудиторії.

Приміром, стаття "100 найвизначніших книг 2019 року” (“100 Notable Books of 2019”) з додатка Book Reviews до часопису New York Times представляє лише три перекладні книги, які ввійшли до сотні кращих (це, відповідно, становить тільки 3\%). Загалом, у США за 2018 р. було опубліковано лише 609 перекладних книг поезії та прози, що становить близько 4\% від загальної кількості усіх видань, що чітко демонструє другорядну позицію іноземних перекладних книг для американського читача. Художні переклади в США зазвичай з'являються з іспанської (101 книга за 2018 р.), французької (99 книг) та німецької (53 видання) мов, які стають найпомітнішими на книжковому ринку. За даними найбільш репрезентативної бази англійських перекладів іноземної художньої літератури у США Publishers Weekly, заснованої на базі Рочестерського університету, 2018 р. було опубліковано тільки 4 книги, перекладених з української мови: роман "Месопотамія" С. Жадана, науковофантастичний роман I. I. Мендор "Ера Емілія", збірка оповідок Остапа Вишні під назвою "Hard Times" та добірка поезії "Songs for a Dead Rooster" Ю. Андруховича в англомовних інтерпретаціях В. Чернецького та О. Коня. Отож, якщо цільова система 
культури є доволі самодостатньою завдяки політично-економічній складовій, то при рецептивному аналізі варто враховувати увесь спектр “тотального перекладу" (в термінології П. Торопа [10]) української культури - від власне текстових до метатекстових (англомовні рецензії та огляди українських видань, наукові статті та університетські курси про українську культуру й літературу) та інтертекстових перекладів (запозичення та вкраплення цитат, алюзій та інтертекстем з українських творів у цільовий наратив), які сукупно формують горизонт англомовного читача. Нарешті, тотальний переклад водночас формує культурний капітал та залежить від нього, визначаючи рівень інтеграції іноземної літератури у цільовий соціальний простір.

Услід за П. Бурдьє, вважаємо, що успішні перекладацькі проєкти треба трактувати символічним капіталом вихідної культури, яка сприймається і визнається цільовими агентами (читачами, критиками, редакторами, видавцями та ін.) як цінність відповідно до їхніх категорій сприйняття. Певна річ, процесуально набуття символічного капіталу залежить від низки чинників: політики та інституційної відкритості в культурі реципієнта, культурного й соціального капіталу вихідної літератури та габітусу перекладачів, тобто системи латентних цінностей та диспозицій, інтеріорізованих ними у процесі соціалізації в координатах культури-реципієнта. П. Бурдьє вказує, що габітус створює умови для прояву свободи вибору агента (у нашому випадку перекладача) і водночас обмежує його суб'єктивні стремління шляхом формування бар'єрів, встановлення меж активності індивідів. Тобто через габітус певні структури можуть керувати практикою, адже він конструює для агента певну матрицю, що дає можливість орієнтуватися в соціальному просторі й адекватно реагувати на події та ситуації [12].

Симптоматично, що автор однієїз новітніх концепцій аналізу рецепціїлітературних творів, Е. Андрінга, моделює три ключові параметри, які стисло віддзеркалюють вищезгадані підходи до вивчення рецепції:

1) знання про праці та творчість представників заданої культури, що слугують “фреймами” чи каркасом для ідентифікації та наративізації інших творів;

2) інтерналізовані та загально засвоєні стратегії та конвенції, які керують створенням, рецепцією та “комунікацією” творів у заданому суспільстві;

3) система цінностей, мотивів та смислів, які визначають відбір, класифікацію та оцінку творів [11, с. 501].

У схожій площині працює Г. Дорлейн, наголошуючи, що для вивчення рецепції перекладного твору варто дослідити культурний репертуар цільової аудиторії у розрізі трьох компонентів: 1) змістовий компонент - структура чи корпус “архетекстів", 2) нормативний компонент - правила і норми створення творів, 3) функційний аспект: інструменти для набуття культурного та символічного капіталу творами [15]. Обидві концепції наголошують на тому, що при розгляді перекладів творів українських авторів в іншомовному просторі мусимо зважати на низку дискретних чинників, деякі з яких експліцитно й наскрізно зафіксовано в працях Р. П. Зорівчак при аналізі внутрішньої логіки та динаміки чужомовної рецепції українського слова. Щобільше, саме у серії розвідок дослідниці підкреслено ще один важливий вимір: поява української 
літератури в перекладах залишається одним із способів іiі самоінтерпретації та спробою заявити, що вона існує і становить окремий і неповторний образний світ. Тому доцільно відзначити ще додаткові штрихи до розуміння рецепції, які відкриваються власне у площині вивчення українсько-англійського культурного трансферу в доробку Р. П. Зорівчак.

Деякі з перших перекладів українських фольклорних творів та віршів Т. Шевченка зроблено не 3 оригіналу [5, с. 92; 5, с. 104], а з їхніх польських або російських перекладів (часом досить невдалих), що загалом маркує опосередкований напрям тодішніх інтерпретацій українських текстів та тенденційність непрямого перекладу. Це можна пояснити навіть тим фактом, що перший двомовний перекладний словник 3 українською мовою як мовою-джерелом з'явився лише у 1885-1886 рр. (йдеться про українсько-німецький словник Є. Желехівського та С. Недільського) [5], тобто “доступ” до мови був доволі ускладнений. Отож, рецепція української літератури в англомовному просторі залежала від іiі культурного трансферу в польськомовне, російськомовне чи німецькомовне поля.

3 огляду на це, спостерігаємо, що для сприйняття українського фольклору в англомовному просторі XIX ст. відіграли також велику роль “метатекстові переклади" (за П. Торопом) на чужомовні інтерпретації, скажімо - англійські рецензії в періодиці на першу німецьку антологію української народної поезії “Die poetische Ukraine” поета й перекладача Ф. Боденштадта або ж на французькі переклади А. Ходзька українських історичних пісень [5, с. 94-96].

Доповненням до цього вважаємо той факт, що перші британські перекладачі української літератури були славістами, які передусім спеціалізувалися на російській, чеській чи польській філології. Тому їхнє звернення до творчості українських авторів було радше фрагментарним.

Перші переклади українських текстів публікувалися у форматі загальних антологій, зібрань чи колекцій творів, титульні назви яких масштабували географічний ареал або до слов'янських джерел, як-от “Sixty folk tales from exclusively Slavonic sources, translated into English prose” А.-Г. Вратіслава (Лондон, 1889), або до літератури тогочасної Російської імперії, приміром "Тhe Russian troubadour" (Лондон, 1816) чи простору Радянського Союзу, для прикладу "Folk tales of the peoples of the Soviet Union” (Лондон, 1945); відтак, українська етнокультурна ідентичність залишалася фактично в тіні. Однак перша англомовна художня книжка, перекладена з української мови поліглотом і науковцем з Британського музею Р. Н. Бейном, була видана 1894 p. майже одночасно у Лондоні та Нью-Йорку під назвою "Cossack fairy tales and folk tales”, де українську мову було ідентифіковано як козацьку, а передмова позиціонувала український народ та його фольклор як самостійну єдність [5, с. 106].

До початку XX ст. представлення української творчості в англомовному просторі відбувалося з опорою на Шевченка й фольклор, іншими словами, в межах народницької естетичної парадигми, i, без сумніву - в заломленні тогочасного імперського дискурсу Poсії. У XX ст. можна виокремити дві траєкторії “перевідкриття” української культури, перша $з$ яких - пропозиція англійських перекладів ширшого спектру творів українських авторів, але виконаних здебільшого “внутрішньо” - у Радянському Союзі. 
Зокрема, київське видавництво “Дніпро” з 1971 до 1989 рр. випустило 117 англійських перекладних книг. Очевидно, таке позиціонування модифікує їхню рецепцію. Інша траєкторія - проекти та діяльність українських інтелектуалів в еміграції. Усередині XX ст. Ю. Шерех писав, що "наш літературний світ - катастрофічно тоненька плівка", журнали слабенькі, перекладів мало, а "наше мистецтво - вияв нашої духовності - не знаходить резонансу серед чужинців”, бо існує “конфлікт естетик”, й наша література позначена "безнадійною провінційністю" та "нерозумінням часу" [9, с. 312-313]. Викликом, без сумніву, було й те, що українські твори не звучали “сучасними” в сенсі їхньої модерності, відтак переклади не набували чималого розголосу. Така початкова ситуація відчувалася, мабуть, через нестачу інституційної підтримки, яка б лобіювала реноме української літератури; одначе з часом спостерігаємо створення інституційного середовища (Наукове товариство Шевченка в США, Інститут українських студій в Гарварді тощо), що відкриває новий виток у репрезентації українського культурного ландшафту.

Ці спостереження нагадують нам про необхідність синтезу та випрацювання загального механізму для вивчення рецепції перекладної літератури в інокультурному просторі, який би показав усю складність конструювання перекладу й осмислення читацької рецепції. Отже, моделюємо п'ять вимірів, які дають змогу поглянути на перекладний твір у чужомовному просторі в різній оптиці (рис. 1).

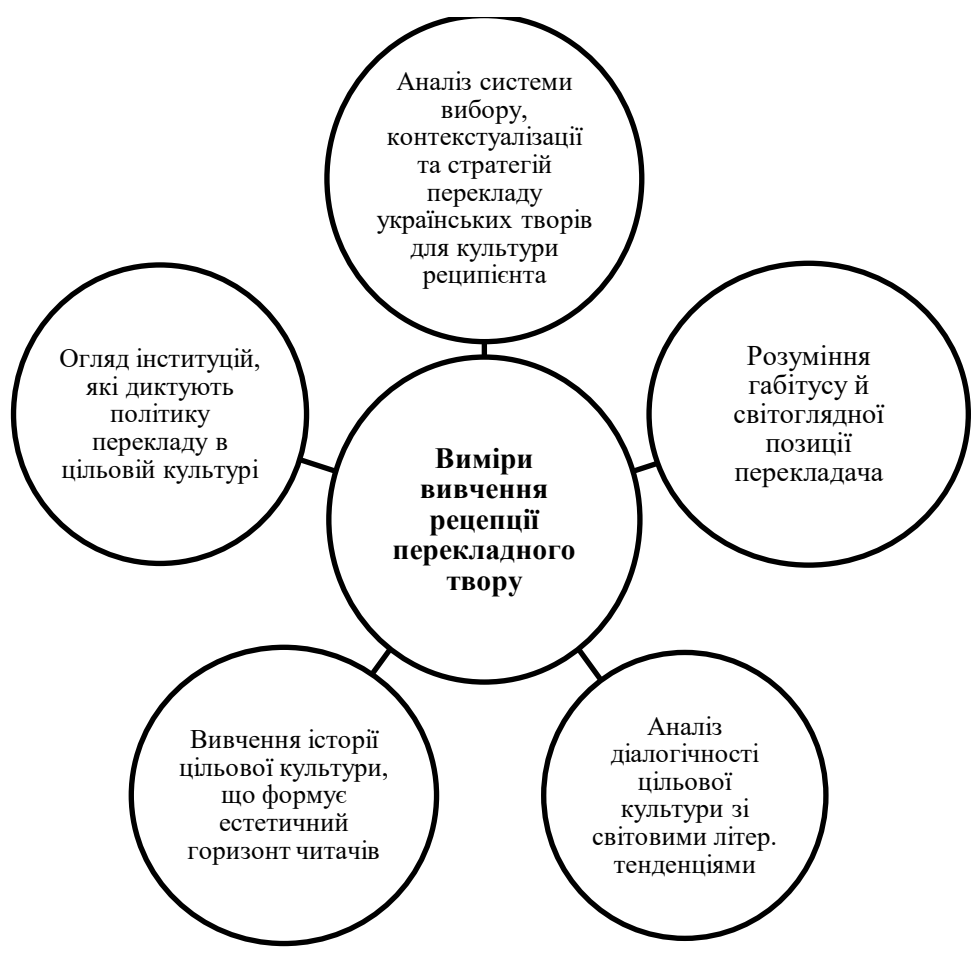

Рис. 1. Аналітична модель вивчення рецепції перекладного твору в інокультурному просторі. 
Ці виміри чітко окреслюють чинники, які мають вплив та визначають рецепцію перекладного твору, зокрема:

1) аналіз інституційних структур (міністерства культури, фонди, інститути книг, видавництва, спілки перекладачів тощо), які диктують політику перекладу в цільовій системі, формують норми, тенденції та суспільні конвенції в трактуванні перекладів, надають взірці успішних перекладацьких проектів та загалом утверджують етику та поведінку учасників перекладацького процесу;

2) вивчення иільової культурної історії, зосібна впливу минулих культурних практик на сучасні, котрі формують естетичний горизонт читачів, їхній світогляд та стереотипні уявлення. Окрему увагу варто тут звертати на “ефект публіки”, скерований на те, щоб осягнути, чому певні форми та жанри мають успіху серед аудиторії, а інші - приреченні на швидке забуття.

3) огляд рівня діалогічності культури реципієнтів зі світовими літературними тенденціями загалом та вихідною культурою зокрема. Якщо деякі культури відкриті, солідарні з глобальним контекстом, оперативно відстежують популярні новинки на книжкових ринках та одразу пропонують переклади, то інші літератури позиціонуються відносно закритими, для яких інтеграція завжди проходить повільно, “фільтровано" та з опорою на соціокультурну диференціацію. Безперечно, існують системи, де співіснують ці рівні діалогічності в залежності від часопростору та зовнішніх політичних чинників;

4) персонологічний вимір є вкрай важливим, адже диспозиції, статус та рівень праці перекладача відіграє суттєву роль у його співпраці з видавництвами, промоцією та контекстуалізацією перекладного твору.

5) не менш вагомим для дослідження є аналіз системи вибору творів для перекладу та розуміння їхнього взаємозв'язку з попередніми текстами, які створюють дискурс про певну культуру в чужомовному ареалі, а також формат представлення перекладів (осібні видання чи антології та колекції творів, або оприсутнення перекладів на сторінках періодики). Акцент у цьому вимірі також ставиться на аналіз паратекстів, які націлені на наближення твору до цільового читача.

Запропонований поділ досить умовний і не має детермінованого характеру, а радше створює умовні лінії для наближення до осягнення рецепційного клімату та сприйняття перекладного твору в інокультурному просторі.

Висновки та перспективи подальших досліджень. Якщо сьогодні одна 3 основних цілей українських культурних інституцій - це розширення глобального діапазону представлення та, відповідно, зацікавлення літературою України, органічно вписуючи iï у світовий контекст, то варто започаткувати принципово інший - міждисциплінарний - дискурс (з головним фокусом на літературознавчих та перекладознавчих студіях) для критичного прочитання англомовних інтерпретацій та їхньої рецепції серед аудиторії. Ця стаття - лише спроба окреслити механізм вивчення рецепції та культурного трансферу перекладів українських творів на основі фундаментальних історичних праць про українсько-англійські взаємини Р. П. Зорівчак. У перспективі варто "розгортати" ці погляди методологічно та фактографічно й створити новий цілісний історичний наратив про рецепцію української літератури в англомовному просторі з $1991 \mathrm{p}$. 


\section{СПИСОК ВИКОРИСТАНОЇ ЛІТЕРАТУРИ}

1. Антологія світової літературно-критичної думки XX ст. / за ред. М. Зубрицької. Львів : Літопис, 2001. 832 c.

2. Забужко O. Notre Dame d’Ukraine: Українка в конфлікті міфологій. Київ : Факт, 2007. $640 \mathrm{c}$.

3. Зорівчак Р. Сприйняття творчості та особистості Івана Франка як символу інтелектуальної України в англомовному світі. Украӥнське літературознавство. Львів : Вид-во ЛНУ ім. І. Франка, 2014. Вип. 78. С. 3-14.

4. Зорівчак Р. Творчість Лесі Українки в англомовному світі. Леся Украӥнка і сучасність. Луцьк : РВВ “Вежа” Волин. нац. ун-ту ім. Лесі Українки, 2008. Т. 4, кн. 2. С. 48-62.

5. Зорівчак Р. П. Українсько-англійські літературні взаємини. Українська література в загальнослов'янському і світовому літературному контексті. Т. 3. Київ : Наукова думка, 1988. С. 88-154.

6. Зорівчак Р. Шевченкознавство в англомовному світі: історія, своєрідності, ключові здобутки (1876-2014). Тарас Шевченко: Апостол правди і науки: Матер. Міжнар. наук. конф. Львів : ЛНУ ім. І. Франка, 2015. С. 20-33.

7. Літературознавча енциклопедія: у 2 т. / за ред. Ю. Коваліва. Київ : Академія. 2007.

8. Новикова М. Міфи та місія. Київ : Дух і літера, 2005. 426 с.

9. Павличко С. Теорія літератури. Київ : Основи, 2009. 679 с.

10. Тороп П. Тотальний переклад. Вінниця : Нова книга, 2015. 264 с.

11. Andringa E. Penetrating the Dutch polysystem: the reception of Virginia Woolf, 1920 2000. Poetics Today. 2006. № 27 (3). P. 501-568.

12. Bourdieu P. Social Space and Symbolic Power. Sociological Theory. 1989. Vol. 7, № 1 (Spring). P. 14-25.

13. Casanova P. The World Republic of Letters. Cambridge, Mass. : Harvard University Press, 2005. 440 p.

14. Damrosch D. What is World Literature? Princeton : Princeton University Press, 2003. $344 \mathrm{p}$.

15. Dorleijn G., Vanstiphout H. Cultural Repertoires. Structure, Function and Dynamics (Groningen Studies in Cultural Change). Leuven : Peeters Publishers, 2003. 249 p.

16. Literary Translation and Cultural Mediators in 'Peripheral' Cultures. Customs Officers or Smugglers? / ed. by D. Roig-Sanz, R. Meylaerts. London : Palgrave Macmillan, 2018. $373 \mathrm{p}$.

17. Perspectives on Literature and Translation. Creation, Circulation, Reception / ed. by Brian Nelson and Brigid Maher. New York : Routledge, 2013. 231 p.

18. Sontag S. At the same time: Essays and speeches. London : Hamish Hamilton, 2007. 256 p.

19. Ukrainian literature in English: Books and pamphlets, 1890- 1965: An annotated bibliography / compl. by M. Tarnawsky. Edmonton, Alta, 1988; Ukrainian literature in English: Articles in journals and collections, 1840-1965 : An annotated bibliography / compl. by M. Tarnawsky. Edmonton, Alta, 1992; Ukrainian literature in English: 1980 1989 : An annotated bibliography / compl. by M. Tarnawsky. Edmonton \& Toronto, 1999; Ukrainian Literature in English. A Selected Bibliography of Translations 2000- . Ukrainian Literature: A Journal of Translations. 2004. Vol. 1; 2007. Vol. 2; 2011. Vol. 3; Ukrainian literature in English: 1966-1979 : An annotated bibliography / compl. by M. Tarnawsky. Edmonton, 2010; Ukrainian Literature in English.Selected articles in journals and collections publ. since 2000 / compl. by M. Tarnawsky. Ukrainian Quarterly. 2010. Spring-Summer. 


\section{REFERENCES}

1. Antologhija svitovoji literaturno-krytychnoji dumky XX st. [Anthology of the World Literary Critical Thought of the $20^{\text {th }}$ century] / za red. M. Zubrycjkoji. Lviv : Litopys, 2001. $832 \mathrm{~s}$

2. Zabuzhko O. Notre Dame d'Ukraine: Ukrajinka v konflikti mifologhij [Notre Dame d'Ukraine: Ukrainka in the Conflict of Mythologies]. Kyiv : Fakt, 2007. 640 s.

3. Zorivchak R. Spryjnjattja tvorchosti ta osobystosti Ivana Franka jak symvolu intelektualjnoji Ukrajiny $\mathrm{v}$ anghlomovnomu sviti [The perception of the creative activities and personality of Ivan Franko as a symbol of intellectual Ukraine in the Anglophone world]. Ukrajinsjke literaturoznavstvo. Lviv : Vyd-vo LNU im. I. Franka, 2014. Vyp. 78. S. 3-14.

4. Zorivchak R. Tvorchist Lesi Ukrajinky v anghlomovnomu sviti [The Legacy of Lesia Ukrainka in the Anglophone World]. Lesja Ukrajinka i suchasnist. Lutsk : RVV "Vezha" Volyn. nac. un-tu im. Lesi Ukrajinky, 2008. T. 4, kn. 2. S. 48-62.

5. Zorivchak R. P. Ukrajinsjko-anghlijsjki literaturni vzajemyny [Ukrainian-English literary relations]. Ukrajinsjka literatura $v$ zaghaljnoslov'jansjkomu $i$ svitovomu literaturnomu konteksti. T. 3. Kyiv : Naukova dumka, 1988. S. 88-154.

6. Zorivchak R. Shevchenkoznavstvo v anghlomovnomu sviti: istorija, svojeridnosti, kljuchovi zdobutky (1876-2014) [Shevchenko studies in the Anglophone world: history, specificities, key achievements (1876-2014)]. Taras Shevchenko: Apostol Pravdy i Nauky: Mat. Mizhnar. nauk. konf. Lviv : LNU im. I. Franka, 2015. S. 20-33.

7. Literaturoznavcha encyklopedija [The Literary Encyclopaedia]: u 2 t. / za red. Ju. Kovaliva. K.: Akademija. 2007.

8. Novykova M. Mify ta misija [Myths and Mission]. Kyiv : Dukh i litera, 2005. $426 \mathrm{~s}$.

9. Pavlychko S. Teorija literatury [Theory of Literature]. Kyiv : Osnovy, 2009. 679 s.

10. Torop P. Totaljnyj pereklad [Total Translation]. Vinnytsia : Nova knygha, 2015. $264 \mathrm{~s}$.

11. Andringa E. Penetrating the Dutch polysystem: the reception of Virginia Woolf, 1920-2000. Poetics Today. 2006. № 27 (3). P. 501-568.

12. Bourdieu P. Social Space and Symbolic Power. Sociological Theory. 1989. Vol. 7, № 1 (Spring). P. 14-25.

13. Casanova P. The World Republic of Letters. Cambridge, Mass. : Harvard University Press, 2005. $440 \mathrm{p}$.

14. Damrosch D. What is World Literature? Princeton : Princeton University Press, 2003. $344 \mathrm{p}$.

15. Dorleijn G., Vanstiphout H. Cultural Repertoires. Structure, Function and Dynamics (Groningen Studies in Cultural Change). Leuven : Peeters Publishers, 2003. 249 p.

16. Literary Translation and Cultural Mediators in 'Peripheral' Cultures. Customs Officers or Smugglers? / ed. by D. Roig-Sanz, R. Meylaerts. London : Palgrave Macmillan, 2018. $373 \mathrm{p}$.

17. Perspectives on Literature and Translation. Creation, Circulation, Reception / ed. by Brian Nelson and Brigid Maher. New York : Routledge, 2013. $231 \mathrm{p}$.

18. Sontag S. At the same time: Essays and speeches. London : Hamish Hamilton, 2007. 256 p.

19. Ukrainian literature in English: Books and pamphlets, 1890- 1965: An annotated bibliography / compl. by M. Tarnawsky. Edmonton, Alta, 1988; Ukrainian literature in English: Articles in journals and collections, 1840-1965 : An annotated bibliography / compl. by M. Tarnawsky. Edmonton, Alta, 1992; Ukrainian literature in English: 19801989 : An annotated bibliography / compl. by M. Tarnawsky. Edmonton \& Toronto, 1999; Ukrainian Literature in English. A Selected Bibliography of Translations 2000. - Ukrainian 
Literature: A Journal of Translations. 2004. Vol. 1; 2007. Vol. 2; 2011. Vol. 3; Ukrainian literature in English: 1966-1979 : An annotated bibliography / compl. by M. Tarnawsky. Edmonton, 2010; Ukrainian Literature in English.Selected articles in journals and collections publ. since 2000 / compl. by M. Tarnawsky. Ukrainian Quarterly. 2010. Spring-Summer.

\title{
MODELLING THE RECEPTION STUDIES OF UKRAINIAN LITERATURE IN THE TARGET CULTURAL SPACE
}

\section{Iryna Odrekhivksa}

\author{
Ivan Franko National University of Lviv, \\ 1, Universytetska Str., Lviv, Ukraine, 79000 \\ iryna.odrekhivska@lnu.edu.ua
}

The current paper aims to present a systematic and insightful re-reading of the key works authored by R. Zorivchak on one of the central topics of her scholarly interests - Ukrainian-English literary relations through the translational lens. The ultimate goal of this study is to further develop the model for the analysis of the reception of Ukrainian literature in the target cultural field. The conceptual and historiographic premises of the research projects by R. Zorivchak, as well as the gravitational points in the thematic scope of her reception studies, i.e. the history of translating the oeuvre of Taras Shevchenko, Ivan Franko and Lesia Ukrayinka into English in the cultural spaces of Great Britain and the US, Canada and Australia are taken as a starting point. Re-visiting the methodological tenets of the reception aesthetics (H. R. Jauss and W. Iser), polysystem theory (I. Even-Zohar and G. Toury), Bourdieu's sociological theory and recent research projects in world literature, translation and reception studies (E. Andringa, S. Bassnett, P. Casanova, D. Damrosch, S. Sonntag and others), the paper solicits an analytical model to frame the reception studies of translated literature. The proposed model actualizes the following five analytical dimensions: 1) overview of institutional policy that governs translation profiles for the recipient culture; 2) analysis of the target cultural history, which leads to the understanding of readers' aesthetic horizon and the influence of past practices on the present ones; 3 ) analyzing the level and character of dialogicality of the target culture in a certain timespace that lies in the differentiation from or solidarity with the tendencies in world literature in general and target literature in particular; 4) analysis of the personal factor in translation, namely translator's habitus, individual worldview and identity; (5) reviewing the system of selection, contextualization and translation strategies preference in rendering the Ukrainian literary texts into the receiving culture.

Key words: reception, translation, Ukrainian literature, cultural transfer, translated literature, translation studies, policy of translation. 